Al-Bayyinah: Journal of Islamic Law- ISSN: 1979-7486 (p); 2580-5088 (e) Volume VII Number 1, pp. 73- 90

\title{
KEDUDUKAN TAKLIK TALAK MENURUT HUKUM FIKIH DAN KOMPILASI HUKUM ISLAM
}

\section{Hibnu Nugroho}

\section{(Dosen Fakultas Hukum Universitas Jenderal Soedirman)}

\section{Abstract}

The fundamental difference between Jurisprudence Law and Islamic Law Compilation regarding Taklik Talak in Jurisprudence Law and Compilation of Islamic LaW According to Fiqh Law is explained in Ahwal Asyakhsiyyah and other book sources states that if taklik talak is violated by the husband, divorce will automatically fall without the consent of the husband and without a verdict from the court Religion and falling talaq are triple divorce. In contrast to the Compilation of Islamic Law mentioned in Article 45 and Article 46, it is explained that divorce falling from Taklik Talak violations can only occur in front of the Religious Court Session with the stipulation that taklik talak is truly pronounced and signed by the husband as authentic evidence that the husband is right violating his divorce pledge and as a judge's judgment in determining his decision.

Kata Kunci: Taklik talak, hukum fikih, Kompilasi Hukum Islam 


\section{A. Latar Belakang}

Perkawinan adalah perjanjian suci antara seorang lakilaki dan seorang perempuan untuk membentuk keluarga bahagia. Untuk melaksanakan perkawinan tersebut harus memenuhi rukun dan syarat-syaratnya. Salah satu rukun perkawinan adalah ijab dan qabul. Hal ini dilakukan oleh wali dari pihak calon istri dengan calon mempelai laki-laki, dengan ucapan ijab qabul tersebut, maka antara keduanya telah terikat dalam perkawinan yang sah. Kemudian dilanjutkan dengan pembacaan Shîghat Taklik Talak.

Taklik talak menurut pengertian hukum Indonesia merupakan perjanjian yang dimana suami menggantungkan terjadinya suatu talak atas istrinya apabila ternyata dikemudian hari suami melanggar salah satu atau semua yang ada dalam perjanjian taklik talak.

Lembaga taklik talak di Indonesia telah ada sejak zaman dahulu. Kenyataan yang ada sampai saat ini pun menunjukkan hampir setiap perkawinan di Indonesia yang dilaksanakan menurut agama Islam selalu diikuti pengucapan sighat taklik oleh suami. Sekalipun sifatnya suka rela, namun di negara ini, membaca taklik talak seolah-olah menjadi kewajiban yang harus dilaksanakan oleh suami.

Berdasarkan Maklumat Kementerian Agama Nomor 3 Tahun 1953, Departemen Agama menganjurkan kepada pejabat daerah agar dalam pernikahan itu dibacakan taklik talak. Taklik talak merupakan pernyataan jatuhnya talak atau cerai sesuai dengan janji yang diucapkan. Dalam hukum Indonesia taklik talak diartikan sebagai perjanjian yang diucapkan oleh calon mempelai pria setelah akad nikah yang dicantumkan dalam akta nikah berupa janji talak yang digantungkan kepada suatu keadaan tertentu yang mungkin terjadi di masa yang akan datang.

Taklik talak dalam pengertian hukum Indonesia khususnya dalam Kompilasi hukum islam telah memiliki perubahan maksud sebagaimana yang dikehendaki dalam kitabkitab fikih. KHI telah melakukan terobosan baru dalam

${ }^{1}$ Kamal Muchtar, Asas-asas hukum Islam tentang Perkawinan (Jakarta: Bulan Bintang),h. 207. 
pembaruan hukum Islam, terlihat pada kekuatan hukum pada taklik talak didalam fiqih suami mengikrarkan taklik talak cukup secara lisan, namun berdasarkan dalam KHI pada pasal perjanjian perkawinan tentang dibenarkannya taklik talak dalam perkawinan selama perjanjian yang berupa taklik talak ini diucapkan dan ditandatangani oleh suami setelah akad nikah dilangsungkan yang sighat takliknya ditentukan oleh menteri agama dan catatanya disertakan dalam bentuk surat nikah.

Perbedaan antara hukum fikih dan Kompilasi Hukum Islam tentang keberadaan taklik talak jika tidak dipahami secara mendalam maka akan melahirkan banyak kontroversi di berbagai kalangan.

\section{B. Rumusan Masalah}

Adapun rumusan masalah pada penelitian ini sebagai berikut:

1. Bagaimana pandangan hukum fikih tentang pengucapan taklik talak dalam pernikahan?

2. Bagaimana ketentuan hukum taklik talak dalam Kompilasi Hukum Islam?

\section{Tujuan dan Kegunaan Penelitian}

Adapun tujuan penelitian ini adalah:

1. Untuk mengetahui dan menganalisis pandangan hukum fikih tentang pengucapan taklik talak dalam pernikahan.

2. Untuk mengetahui dan menganalisis ketentuan hukum taklik talak dalam kompilasi hukum Islam.

Sedangkan kegunaan penelitian ini sebagai berikut:

1. Diharapkan berguna untuk perkembangan wacana hukum Islam khususnya yang berkaitan dengan pokok masalah penelitian

2. Memberikan pandangan baru bagi masyarakat tentang perlunya taklik talak ini dibacakan setalah akad nikah dalam perkawinan Islam 


\section{Metodologi Penelitian}

Penelitian ini menggunakan jenis penelitian kepustakaan yang menggunakan data sekunder yang bersumber dari 3 bahan hukum yaitu:

1. Bahan hukum primer, meliputi Kompilasi Hukum Islam dan Peraturan Menteri Agama No 3 tahun 1975 Tentang Kewajiban-Kewajiban Pegawai Nikah Dan Tata Kerja Pengadilan Agama Dalam Melaksanakan Peraturan Perundang-Undagan Perkawinan Bagi Yang Beragama Islam.

2. Bahan hukum sekunder, yaitu kitab-kitab fikih atau pendapat para ulama/mazhab tentang taklik talak serta literatur-literatur yang mempunyai relevansi dengan pembahasan.

3. Bahan hukum tersier, meliputi kamus, ensiklopedia, dsb.

Penelitian ini menggunakan pendekatan yuridis (pendekatan Perundang-Undangan) dan pendekatan konseptual. Cara pengolahan bahan hukum dilakukan secara induktif. Selanjutnya bahan hukum yang ada dianalisis secara deskriptif. Kemudian setelah itu dilakukan analisis keseluruhan aspek untuk memahami makna hubungan antara aspek yang satu dengan lainnya dan dengan keseluruhan aspek yang menjadi pokok permasalahan penelitian yang dilakukan secara induktif sehingga memberikan gambaran hasil secara utuh.

\section{E. Hasil Pembahasan}

\section{Ketentuan Taklik Talak dalam Perkawinan}

Perkawinan ialah akad yang menghalalkan pergaulan antara seorang laki-laki dan seorang perempuan karena ikatan suami istri,dan membatasi hak dan kewajiban antara seorang laki-laki dan seorang perempuan yang bukan mahram $^{2}$. Dalam bahasa Indonesia, perkawinan berasal dari kata "kawin" yang menurut bahasa artinya membentuk keluarga dengan lawan jenis; melakukan hubungan kelamin atau bersetubuh. Perkawinan disebut juga "pernikahan", berasal dari kata nikah (نكاح) yang menurut bahasa artinya

${ }^{2}$ Beni ahmad Saebani, Fiqh Munaqahat 1 (Bandung: CV.Pustaka Setia,2001), h. 9. 
mengumpulkan, saling memasukkan, dan digunakan untuk arti bersetubuh (wathi) ${ }^{3}$. Abu Zakariya Al-Anshary mendefinisikan, sebagaimana yang dikutip oleh Abdul Rahman Ghozali:

Artinya:

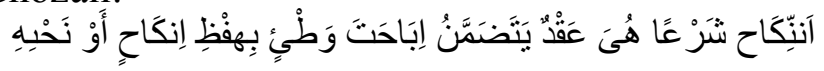

"Nikah menurut istilah syara' ialah akad yang mengandung ketentuan hukum kebolehan hubungan seksual dengan lafaz nikah atau dengan kata-kata yang semakna dengannya."

Adapun hukum melaksanakan pernikahan, sebagai berikut:

a. Hukumnya wajib, yaitu bagi orang yang telah mempunyai kemauan dan kemampuan untuk kawin dikhawatirkan akan tergelincir pada perbuatan zina seandainya tidak kawin.

b. Hukumnya sunat, yaitu orang yang telah mempunyai kemauan dan kemampuan untuk melangsungkan perkawinan, tetapi kalau tidak kawin tidak dikhawatirkan akan berbuat zina.

c. Hukumnya haram, yaitu bagi orang yang tidak mempunyai keinginan dan tidak mempunyai kemampuan serta tanggung jawab untuk melaksanakan kewajiban-kewajiban dalam rumah tangga sehingga apabila melangsungkan perkawinan akan terlantarlah dirinya dan istrinya.

d. Hukumnya makruh, yaitu Bagi orang yang mempunyai kemampuan untuk melakukan perkawinan juga ukup mempunyai kemampuan untuk menahan diri sehingga tidak memungkinkan dirinya tergelincir berbuat zina sekiranya tidak kawin. Hanya saja orang ini tidak mempunyai keinginan yang kuat untuk dapat memenuhi kewajiban suami istri dengan baik.

e. Hukumnya mubah, yaitu bagi orang yang mempunyai kemampuan untuk melakukannya, tetapi apabila tidak 2008), h. 7.

${ }^{3}$ Abdul Rahman Ghozali, Fiqh Munakahat (Jakarta: Kencana,

${ }^{4}$ Abdul Rahman Ghozali, Fiqh Munakahat, h.8. 
melakukannya tidak dikhawatirkan akan berbuat zina dan apabila melakukannya juga tidak akan menelantarkan istri. ${ }^{5}$

Adapun syarat-syarat perkawinan, yaitu adanya calon mempelai laki-laki, adanya calon mempelai perempuan, adanya wali nikah, adanya dua orang saksi, adanya mahar (mas kawin), dan ucapan ijab dan qabul. Pelembagaan taklik talak di mulai dari perintah Sultan Agung Hanyakrakusuma, raja Mataram (1554 Jawa/1630 Masehi) dalam upaya memberi kemudahan bagi wanita untuk melepaskan ikatan perkawinan dari suami yang meninggalkan pergi dalam jangka waktu tertentu, disamping jaminan bagi suami bila kepergian itu adalah dalam rangka tugas negara.

Setelah Belanda datang ke Indonesia didapati kenyataan bahwa taklik talak telah hidup dalam masyarakat. Pertama kali menemukan taklik talak yang dalam bahasa Belanda disebut voorwaardelijke verstoting di Indonesia adalah Snouck Hurgronje ketika membahas masalah hukum adat.

Bentuk pengakuan Kolonial Belanda terhadap hukum Islam di Indonesia pada tahun 1882 berdasarkan Staatsblad 1882 No. 152 dibentuklah Peradilan Agama yang diberi nama Priesterraden atau disebut Raad Agama atau Rapat Agama atau Pengadilan Agama. Dinyatakan berlaku sejak tanggal 1 Agustus 1882 yang dimuat dalam Staatsblad 1882 No. $153 .{ }^{6}$ Untuk pemberlakuan taklik talak maka keluarlah Ordonansi Pencatatan Perkawinan Stb. 1895 No. 198 jis Stb 1929 No. 348 dan Stb. 1931 No. 348, Stb. 1933 No. 98 yang berlaku untuk Solo dan Yogyakarta.?

Sejak keluarnya Ordonansi tersebut maka timbulah gagasan para ulama dengan persetujuan Bupati untuk melembagakan taklik talak sebagai sarana pendidkan bagi para suami agar lebih mengerti kewajiban terhadap isteri,

${ }^{5}$ Abdul Rahman Ghozali, Fiqh Munakahat, h.21.

${ }^{6}$ Amrullah Ahmad, Dimensi Hukum Islam dalam Sistem Hukum Nasional (Jakarta: Gema Insani, 1996), h.51.

${ }^{7}$ Zaini Ahmad Noeh, "Pembacaan Sighat Taklik Talak Sesudah Akad Nikah, Mimbar Hukum,(Jakarta:Ditbinbapera, 1997) h.65-66 
dengan beberapa tambahan rumusan sighat, termasuk kewajiban nafkah dan tentang penganiayaan jasmani. Selanjutnya sighat taklik talak tidak lagi diucapkan oleh Pegawai Pencatat Nikah, tetapi dibaca/diucapkan sendiri oleh suami. Dengan adbanya hal ini, banyak penguasa daerah luar Jawa dan Madura memberlakukannya di daerah masingmasing. Setelah berlakunya Ordonansi Pencatatan Nikah untuk luar Jawa dan Madura, Stb. 1932 No. 482, maka pemberlakuan taklik talak lebih merata di daerah luar Jawa dan Madura. Pada tahun 1925 taklik talak sudah berlaku di daerah Minangkabau, sementara di Muara Tembusai berlaku sejak 1910, begitu juga di Sumatera Selatan, Kalimantan Barat dan Selatan serta Sulawesi Selatan. ${ }^{8}$ Dalam perkembangan selanjutnya rumusan taklik talak semakin disempurnakan, terutama dalam hal melindungi kepentingan isteri. Agar taklik talak tersebut tidak bisa dirujuk suami setelah terjadinya perceraian di depan Pengadilan, maka rumusannya ditambah ketentuan tentang iwad, yakni uang pengganti.

Ketika sighat taklik talak diberlakukan pertama kali di Kerajaan Mataram unsur-unsurnya ada 4 (empat), yakni:

a. Pergi meninggalkan,

b. Isteri tidak rela,

c. Isteri mengadu ke Pengadilan,

d. Pengaduannya diterima Pengadilan.

Pada tahun 1931 ketika taklik talak diberlakukan di sekitar Jakarta dan Tangerang, rumusan sighat taklik talak mengalami penambahan, terutama dari aspek unsurunsurnya. Setelah Indonesia merdeka, rumusan sighat taklik talak ditentukan sendiri oleh Departemen Agama Republik Indonesia.

Sejak berlakunya Undang-undang Nomor 22 Tahun 1946 jo. Undang-undang Nomor 32 Tahun 1952, maka ketentuan tentang sighat taklik talak diberlakukan seragam di seluruh Indonesia. Sejak rumusannya diambil alih Depag, sighat taklik talak mengalami beberapa kali perubahan.

${ }^{8}$ Zaini Ahmad Noeh, "Pembacaan Sighat Taklik Talak Sesudah Akad Nikah, h. 66. 
Perubahan tersebut tidak hanya mengenai unsur-unsur pokoknya, tetapi juga mengenai kualitas syarat taklik yang bersangkutan dan besarnya uang iwadh. Rumusan terakhir sighat taklik talak adalah rumusan yang ditetapkan berdasarkan Peraturan Menteri Agama RI Nomor 2 Tahun 1990. Dari rumusan tersebut ada 10 unsur-unsur pokok sighat taklik talak yakni:

a. Suami meninggalkan isteri, atau;

b. Suami tidak memberi nafkah kepada isteri, atau;

c. Suami menyakiti isteri, atau;

d. Suami membiarkan tidak (memperdulikan) isteri;

e. Isteri tidak rela;

f. Isteri mengadu ke Pengadilan;

g. Pengaduan isteri diterima oleh Pengadilan;

h. Isteri membayar uang iwadh;

i. Jatuhnya talak satu suami kepada isteri;

j. Uang iwadh oleh suami diterimakan kepada Pengadilan untuk selanjutnya diserahkan kepada pihak ketiga untuk kepentingan ibadah sosial.

Taklik talak berarti "penggantungan talak". Takliktalak menurut pengertian hukum Indonesia ialah semacam ikrar yang dengan ikrar itu suami menggantungkan terjadinya suatu talak atas isterinya apabila ternyata dikemudian hari melanggar salah satu atau semua yang telah diikrarkannya itu. 9 Dalam KHI Pasal 1 huruf e, menyebutkan bahwa taklik talak ialah perjanjian yang diucapkan calon mempelai pria setelah akad nikah yang dicantumkan dalam Akta Nikah berupa janji talak yang digantungkan kepada suatu keadaan tertentu yang mungkin terjadi di masa yang akan datang. ${ }^{10}$

\section{Taklik Talak Menurut Hukum Fikih}

Dalam kamus istilah fikih disebutkan, taklik talak adalah menggantungkan jatuhnya talak atas suatu hal, maka

${ }^{9}$ Kamal Mukhtar,. Asas-asas Hukum Islam Tentang Perkawinan, (Jakarta: PT Bulan Bintang, 1993), h. 227

${ }^{10}$ Republik Indonesia, “ Intruksi Presiden Nomor 1 Tahun 1991 Kompilasi Hukum Islam", (Jakarta: Direktorat Jenderal Badan Peradilan Agama, 2005), h. 13 
talak jatuh bila hal itu terjadi. Sedangkan dalam Kompilasi Hukum Islam, taklik talak adalah perjanjian yang diucapkan calon mempelai pria setelah akad nikah yang dicantumkan dalam akta nikah yang berupa janji talak yang digantungkan pada suatu keadaan tertentu yang mungkin terjadi dimasa yang akan datang.

Jumhur Ulama Fiqh mengemukakan syarat bagi berlakuknya taklik talak, yaitu:

a. sesuatu yang belum ada, belum terjadi dan mungkin terjadi.

b. Ketika lafal ta'liq talaq diucapkan suami, wanita tersebut masih berstatus isteri atau masih dalam masa iddah.

c. Ketika syarat yang dikemukakan dalam lafal taklik talak itu terpenuhi, wanita tersebut masih berstatus isteri atau masih dalam masa iddahnya. ${ }^{11}$

Hubungan suami istri dapat menjadi putus berdasarkan taklik talak dengan adanya perjanjian ketentuan taklik talak, yaitu:

a. Menyangkut peristiwa. Peristiwa dimana digantungkan talak berupa terjadinya sesuatu seperti yang telah diperjanjikan.

b. Jika istri sudah tidak rela tersebut mengajukan gugat cerai ke Pengadilan Agama,

c. Istri membayar iwadl sebagai pernyataan tidak senangnya terhadap sikap suami.

d. Dengan membayar iwadl sebesar Rp. 10.000,- itu akan disumbangkan untuk kepentingan ibadah sosial ke Badan Kesejahteraan Masjid. ${ }^{12}$

Sighat taklik talak di Indonesia, baik dari segi bentuk, syarat dan motovasi dibuatnya, berbeda dengan konsep sighat taklik talak yang ada dalam kita-kitab fiqh klasik. Isinya bukan lagi merupakan ancaman suami terhadap isteri, namun berupa janji suami untuk berbuat baik dan

11 Abdul Aziz Dahlan, Ensiklopedi Hukum Islam,( Jakarta: PT. Ikhtiar Baru Van Hoeve, 1996), h.1781.

12 Sudarsono, Pokok-pokok Hukum Islam (Jakarta: Rineka Cipta, 2001), h. 215. 
mempergaulinya dengan mu'asyarah bi al-ma'ruf sesuai dengan syariat Islam.

3. Kedudukan Taklik Talak Menurut Hukum Fikih dan Kompilasi Hukum Islam

Menurut kitab Qawanin al-Syar'iyah, jika taklik talak itu menggunakan kata ان اذا (jika) atau (apaila) atau مني(manakala) dan semacamnya, maka sighat taklik itu berlaku sekaligus, artinya jika telah terjadi perceraian, baik karena talak Raj'i maupun lainnya, maka kekuatan taklik talak yang diucapkan suami gugur adanya. ${ }^{13}$ Lain halnya jika menggunakan kata كلما (sewaktu-waktu), dan ini yang dipakai dalam Permenag. No. 2 Tahun 1990, artinya jika sebelum terwujud syarat taklik kemudian suami menjatuhkan Talak Raj'i dan kemudian suami merujuknya dalam masa iddah, maka taklik talak yang diucapkan suami tetap mempunyai kekuatan hukum, sehingga sewaktuwaktu terwujud syarat Ta'lik, maka isteri dapat menggunakan sebagai alasan gugatan perceraian dengan alasan pelanggaran Ta'lik Talak.

Menurut Sayyid Sabiq, ada dua bentuk talak, yaitu:

a. Al-Tanjiz, artinya talak yang dilakukan oleh suami terhadap isterinya pada waktu seketika.

b. Al-Ta'liq (al-taklik), artinya Talak yang dilakukan oleh suami terhadap isterinya karena ada syarat yang digantungkan. ${ }^{14}$

Di dalam kitab Ahwal Asyaksiyyah menyebutkan ada 3 bentuk Sighat talak:

a. Talak Munjazah, yaitu talak yang langsung tanpa syara.

b. Talak Mu'allaq, yaitu talak yang Sighatnya bersyarat.

c. Talak yang digantungkan pada masa yang akan datang.

Sementara dalam fikih Sunnah, Sayid Sabiq menguraikan bahwa taklik talak ada dua macam bentuk:

a. Taklik qasami adalah taklik yang dimaksudkan seperti janji karena mengandung pengertian melakukan

${ }^{13}$ Sayyid Uthman, Qawanin al-Syar'iyah (Surabaya: Salin Nabhan, t. th.), h. 80 .

${ }^{14}$ As.Sayyed Sabig , Fiqhu al-Sunnah, Jilid II, (Beirut :Darun al Kitabi al Arabiy,1405H), h.260. 
pekerjaan atau meninggalkan suatu perbuatan atau menguatkan suatu kabar.

b. Taklik syarthi adalah taklik yang dimaksudkan untuk menjatuhkan talak jika telah terpenuhi syaratnya. ${ }^{15}$

Adapun syarat sahnya talak taklik ada tiga yaitu:

a. Perkaranya belum ada tetapi mungkin terjadi di kemudian hari jika perkaranya telah nyata ada ketika diucapkan kata-kata talak.

b. Hendaknya ketika lahirnya akad istri dapat dijatuhi talak.

c. Ketika terjadinya perkara yang ditaklikkan istri berada dalam pemeliharan suami.

Jumhur ulama Mazhab berpendapat bahwa bila seseorang telah menta'likkan talaknya yang dalam wewenangnya dan telah terpenuhi syarat-syaratnya sesuai kehendak mereka masing-masing, maka ta'lik itu dianggap sah untuk semua bentuk ta'lik, baik itu mengandung sumpah (qasamy) ataupun mengandung syarat biasa, karena orang yang menta'likkan talak itu tidak menjatuhkan talaknya pada saat orang itu mengucapkannya, akan tetapi talak itu tergantung pada terpenuhinya syarat yang dikandung dalam ucapan ta'lik itu. ${ }^{17}$

Ta'lik talak yang diucapkan suami dapat membawa konsekuensi jatuhnya talak suami kepada isteri apabila dipenuhi syarat sebagai berikut:

a. Bahwa yang dita'likkan itu adalah sesuatu yang belum ada ketika ta'lik diucapkan tetapi dimungkinkan terjadi pada masa yang akan datang.

b. Pada saat ta'lik talak diucapkan obyek ta'lik (isteri) sudah menjadi isteri sah bagi pengucap ta'lik.

c. Pada saat ta'lik talak diucapkan suami isteri berada dalam majelis tersebut.

15 Sayyid Sabiq, Fikih Sunnah, Jilid IV, (Jakarta: Cakrawala publishing, 2012), h. 29.

${ }^{16}$ Sayyid Sabiq, Fiqih Sunnah, Jilid 3, (Jakarta selatan: Pena Pundi Aksara, 2006), h. 154.

${ }^{17}$ Mahmoud Syalthout, Perbandingan Mazhab dan Masalah Fiqh (Jakarta: Bulan Bintang, 1978), h.237. 
Dalam kitab Fikih Sunah, Sayyid Sabiq mengatakan bahwa ucapan ta'liq talaq yang dikaitkan dengan waktu yang akan datang adalah talaq yang diucapkan dikaitkan dengan waktu tertentu sebagai syarat dijatuhkannya talaq, di mana talaq itu jatuh jika waktu yang dimaksud telah datang. Sedangkan dalam buku Hukum Perkawinan Islam menyebutkan talak yang ditakliqkan dengan waktu tertentu akan gugur talaq itu pada permulaan waktu yang disebut itu. Kalau ditentukan ta'liq pada akhir suatu waktu maka talak akan jatuh pada saat-saat terakhir yang ditakliqkan itu.

Dengan demikian, talak yang disandarkan dengan sesuatu syarat (waktu yang akan datang) menurut jumhur Ulama, talaq seperti itu adalah sah, akan tetapi lain halnya dengan pendapat Ibn Hazm yang tidak mengesahkan adanya talaq yang disandarkan, bahkan di Indonesia talaq tersebut jatuh, kecuali jika isteri menjatuhkannya kepada Pengadilan Agama.

Peraturan perundang-undangan tentang taklik talak juga diatur dalam Kompilasi Hukum Islam (KHI) dan Peraturan Menteri Agama No 2 Tahun 1990. Dalam KHI taklik talak diatur dalam Bab VII mengenai Perjanjian Perkawinan yang terdapat dalam pasal 45 dan 46 yang berbunyi:

\section{Pasal 45}

Kedua calon mempelai dapat mengadakan perjanjian perkawinan dalam bentuk :

(1) Taklik Talak, dan

(2) Perjanjian lain yang tidak bertentangan dengan Hukum Islam. ${ }^{18}$

\section{Pasal 46}

(1) Isi taklik talak tidak boleh bertentangan dengan hukum Islam.

(2) Apabila keadaan yang disyaratkan dalam taklik talak betul-betul terjadi kemudian tidak dengan sendirinya talak jatuh. Supaya talak sungguh jatuh, istri harus mengajukan persoalannya ke Pengadilan Agama

${ }^{18}$ Mahkamah Agung, Kompilasi Hukum Islam (Jakarta: Direktorat Badan Peradilan Agama, 2015), h.30. 
(3) Perjanjian taklik talak bukan suatu perjanjian yang wajib diadakan pada setiap perkawinan, akan tetapi sekali taklik talak diperjanjikan tidak dapat dicabut kembali. ${ }^{19}$

Sedangkan Peraturan Menteri Agama No 2 Tahun 1990, diatur dalam Bab III tentang pemeriksaan nikah, pada pasal 11 dan pasal 24 yang berbunyi:

\section{Pasal 11}

(1) Calon suami istri dapat mengadakan perjanjian sepanjang tidak bertentangan dengan hukum Islam dan Peraturan Perundang-undangan yang berlaku.

(2) Perjanjian sebagaimana tersebut pada ayat (1) dibuat rangkap 4 di atas kertas bermaterai menurut peraturan yang berlaku. Lembar pertama untuk suami, lembar kedua untuk istri, lembar ketiga untuk PPN dan lembar keempat untuk Pengadilan.

(3) Perjanjian yang berupa taklik talak dianggap sah jika perjanjian itu dibaca dan ditandatangani oleh suami setelah akad nikah dilangsungkan.

(4) Shîghat taklik talak ditetapkan oleh Menteri Agama.

(5) Tentang ada atau tidak adanya perjanjian sebagaimana dimaksud ayat (1) dan ayat (3) dicatat dalam daftar pemeriksaan nikah.

\section{Pasal 24}

(1) Apabila waktu pemeriksaan nikah calon suami istri telah menyetujui adanya taklik talak sebagaimana dimaksud pasal 11 ayat (3), maka suami membaca dan menandatangani taklik talak sesudah akad nikah dilangsungkan.

(2) Apabila waktu nikah suami mewakilkan qabul kepada orang lain, maka taklik talak itu dibaca dan ditandatangani oleh suami pada waktu yang lain di muka PPN/Pembantu PPN tempat akad nikah dilakukan atau yang mewilayahi tempat tinggalnya.

Pada dasarnya mengucapkan shîghat taklik talak bukan suatu keharusan, karena hal itu dilakukan dengan suka rela. Namun perjanjian taklik talak yang sudah

${ }^{19}$ Mahkamah Agung, Kompilasi Hukum Islam, h.31. 
diperjanjikan tidak dapat dicabut kembali karena bersifat mengikat. ${ }^{20}$ Pada prinsipnya konsekuensi dari taklik talak adalah apabila di kemudian hari benar-benar terjadi apa yang disebutkan dalam shîghat taklik talak, maka secara langsung jatuh talak dengan syarat istri membayar iwadh.

Secara yuridis dalam Permenag. No. 2 Tahun 1990 dkatakan bahwa untuk sahnya perjanjian ta'lik talak, maka suami harus menandatangani sighat ta'lik yang diucapkannya sesudah akad nikah. Dari pernyataan ini dipahami bahwa antara pengucapan dan penandatanganan perjanjian Ta'lik Talak, keduanya bersifat kumulatif. Jika dilihat dari substansinya, ta'lik talak merupakan perjanjian suami isteri yang bersifat sukarela, yang ada atau tidak hanya ditentukan oleh para pihak (suami isteri) dengan tujuan memberikan keadilan bagi masing-masing pihak.

Berdasarkan fakta yuridis, shîghat taklik talak yang ditetapkan oleh Menteri Agama dalam Peraturan Menteri Agama No 2 Tahun 1990 sedikitnya meliputi 10 unsur, yaitu: $^{21}$

a. Suami meninggalkan istri dua tahun berturut-turut, atau;

b. Suami tidak memberi nafkah wajib kepada istri tiga bulan lamanya, atau;

c. Suami menyakiti badan/jasmani istri atau;

d. Suami membiarkan (tidak mempedulikan) istri enam bulan lamanya;

e. Istri tidak rela;

f. Istri mengadukan halnya ke pengadilan;

g. Pengaduan istri diterima oleh pengadilan agama;

h. Istri membayar iwadl;

i. Jatuhnya talak suami satu kepada istri;

20 Ahmad Azhar Basyir, Hukum Perkawinan Islam (Yogyakarta: UII-Press, 2000), h. 83.

${ }^{21}$ Abdul Manan, Penerapan Hukum Acara Perdata di Lingkungan Peradilan Agama (Jakarta: Yayasan Al-Hikmah, 2000), h. 260-261. 
j. Uang iwadl oleh suami diterimakan kepada pengadilan, untuk selanjutnya diserahkan kepada pihak ketiga untuk kepentingan ibadah sosial.

Sejalan dengan tujuan hukum perkawinan untuk tidak membuat perceraian sebagai suatu hal yang mudah untuk dilakukan, Kompilasi Hukum Islam kemudian memandang taklik talak ini bukan sebagai alasan perceraian, tetapi lebih ditempatkan dalam bab tentang perjanjian perkawinan yang dibuat oleh kedua belah pihak. Hal ini dapat dibuktikan dari fakta bahwa taklik talak ini di kategorisasikan dalam kompilasi bukan di bawah bab tentang perceraian (Bab XVI), tetapi justru berada di bawah bab tentang perjanjian perkawinan (Bab VII). Lebih dari itu, pasal 46 dari kompilasi tersebut mengatur bahwa perceraian tidak secara otomatis terjadi, jika syarat yang ada dalam taklik talak dipenuhi, tetapi masih digantungkan pada pengaduan yang secara sungguh-sungguh diajukan oleh istri ke pengadilan agama.

\section{F. Penutup}

Adapun simpulan yang dapat dari hasil penelitian ini sebagai berikut:

1. Pandangan hukum fikih pada taklik talak ini jika suami mengajukan syarat dengan maksud jika syarat tersebut ada maka jatuhlah talak suami pada istrinya. Ulama berbeda pendapat tentang jatuh atau tidaknya talak dengan dua formulasi di atas. Jumhur Ulama berpendapat bahwa jika bentuk taklik yang dikaitkan dengan talak, apabila yang ditaklikkan terjadi maka talaknya jatuh dan talak bersyarat dianggap sah jika yang disyaratkan telah terpenuhi. Jadi jika didalamnya terkandung syarat yang dimaksudkan untuk menjatuhkan talak ketika terjadinya sesuatu yang disyaratkan, maka talak tersebut jatuh tanpa adanya putusan dari pengadilan Agama dan talak yang jatuh dari pelanggaran Taklik talak dalam hukum fikih ini adalah talak bain.

2. Taklik Talak dijelaskan didalam kompilasi hukum Islam Pasal 1 huruf e yakni perjanjian yang diucapkan calon mempelai pria setelah akad nikah yang dicantumkan 
dalam Akta Nikah berupa janji talak yang digantungkan kepada suatu keadaan tertentu yang mungkin terjadi di masa yang akan datang, dan Ketentuan hukum taklik talak diatur dalam KHI Pasal 45 dan pasal 46 yang menyebutkan bahwa taklik talak hanya dapat di perjanjikan bila tidak bertentangan dengan hukum Islam dan sekali taklik talak di perjanjikan maka tidak dapat dicabut kembali dan talak hanya dapat jatuh di depan sidang pengadilan Agama. Diperjelas lagi dalam Peraturan Menteri Agama dalam pasal 11 ayat 3 menyebutkan bahwa taklik talak dianggap sah apabila perjanjian itu di baca dan ditandatangani oleh suami setelah akad nikah dilangsungkan. Jadi jika suami tidak menandatangani kutipan akta nikah, sekalipun dalam akta nikah dijelaskan bahwa suami mengucapkan ta'lik talak, kenyataan ini menunjukkan bahwa salah satu dari kedua syarat sahnya perjanjian ta'lik talak tidak terpenuhi, sehingga akibatnya perjanjian Ta'lik Talak harus dianggap tidak sah atau batal. 


\section{G. Daftar Pustaka}

Agung, Mahkamah. Kompilasi Hukum Islam. Jakarta: Direktorat Badan Peradilan Agama, 2015.

Ahmad, Amrullah. Dimensi Hukum Islam dalam Sistem Hukum Nasional. Jakarta: Gema Insani, 1996.

Basyir, Ahmad Azhar. Hukum Perkawinan Islam. Yogyakarta: UII-Press, 2000.

Dahlan, Abdul Aziz. Ensiklopedi Hukum Islam Jakarta: PT. Ikhtiar Baru Van Hoeve, 1996.

Ghozali, Abdul Rahman. Fiqh Munakahat. Jakarta: Kencana, 2008.

Kamal. Asas-asas Hukum Islam Tentang Perkawinan. Jakarta: PT Bulan Bintang, 1993.

Manan, Abdul. Penerapan Hukum Acara Perdata di Lingkungan Peradilan Agama. Jakarta: Yayasan Al-Hikmah, 2000.

Muchtar, Kamal. Asas-asas hukum Islam tentang Perkawinan. Jakarta: Bulan Bintang.

Noeh, Zaini Ahmad. "Pembacaan Sighat Taklik Talak Sesudah Akad Nikah. Mimbar Hukum. Jakarta:Ditbinbapera,1997.

Republik Indonesia. “ Intruksi Presiden Nomor 1 Tahun 1991 Kompilasi Hukum Islam”. Jakarta: Direktorat Jenderal Badan Peradilan Agama, 2005.

Saebani, Beni ahmad. Fiqh Munaqahat 1. Bandung: CV.Pustaka Setia,2001.

Sabig, as.Sayyed. Fiqhu al-Sunnah. Jilid II. Beirut :Darun al Kitabi al Arabiy,1405H.

- Fikih Sunnah. Jilid IV. Jakarta: Cakrawala publishing, 2012.

. Fiqih Sunnah. Jilid 3. Jakarta selatan: Pena Pundi Aksara, 2006. 
Sudarsono. Pokok-pokok Hukum Islam. Jakarta: Rineka Cipta, 2001.

Syalthout, Mahmoud. Perbandingan Mazhab dan Masalah Fiqh. Jakarta: Bulan Bintang, 1978.

Uthman, Sayyid. Qawanin al-Syar'iyah. Surabaya: Salin Nabhan, t. th. 